\title{
COMPOSITION AND BIOACTIVE PROPERTIES OF YERBA MATE (Ilex paraguariensis A. St.-Hil.): A REVIEW
}

\author{
Kellie P. Burris ${ }^{1}$, Federico M. Harte ${ }^{1 *}$, P. Michael Davidson ${ }^{1}$, C. Neal Stewart, Jr. ${ }^{2}$, \\ and Svetlana Zivanovic ${ }^{1}$
}

Yerba Mate is a popular tea beverage produced and consumed in the South American countries of Argentina, Brazil, Chile, Paraguay, and Uruguay, and is processed from the leaves and stems of Ilex paraguariensis A. St.-Hil., a perennial shrub from the Aquifoliaceae family. Production occurs in six stages: harvesting older leaves and small stems, roasting by direct fire, drying under hot air, milling to specified size, aging to acquire optimal sensory attributes, and final packaging. While grown and consumed for centuries in South America, its popularity is increasing in the United States because of demand by consumers for healthier, more natural foods, its filling a niche for a different type of tea beverage, and for Yerba Mate's potential health benefits - antimicrobial, antioxidant, antiobesity, anti-diabetic, digestive improvement, stimulant, and cardiovascular properties. Cultivation, production and processing may cause a variation in bioactive compounds biosynthesis and degradation. Recent research has been expanded to its potential use as an antimicrobial, protecting crops and foods against foodborne, human and plant pathogens. Promising results for the use of this botanical in human and animal health has prompted this review. This review focuses on the known chemical composition of Yerba Mate, the effect of cultivation, production and processing may have on composition, along with a specific discussion of those compounds found in Yerba Mate that have antimicrobial properties.

Key words: Antioxidant, antimicrobials, natural products, Yerba mate, tea.

$\mathrm{L}$ ittle research has been conducted on the bioactive and chemical composition of yerba mate (Ilex paraguariensis A. St.-Hil.) in comparison to other plantbased beverages such as green tea or coffee. However, within the last two decades, there has been an increased interest in this botanical for its use in human health. Ilex paraguariensis, a native South American holly shrub from the Aquifoliaceae family, is mainly produced and consumed in the countries of Argentina, Brazil, Chile, Paraguay, and Uruguay (Grigioni et al., 2004). Yerba mate, processed from the leaves and small stems of $I$. paraguariensis (Figure 1), is a non-alcoholic beverage consumed socially primarily in these countries, and like coffee, primarily for its caffeine content. Typical consumption of yerba mate is taken from a small cup or "mate". Small amounts of hot water are regularly poured over a serving, ca. $50 \mathrm{~g}$ of packed tea. The beverage is then drunk by using a metal straw or "bombilla", which has small holes that prevent the leaves from being consumed (Kubo et al., 1993; Heck and de Mejia, 2007; Heck et al., 2008).

${ }^{1}$ University of Tennessee, Department of Food Science and Technology, Knoxville, 2605 River Drive, Knoxville, TN 379964591, USA. *Corresponding author (fede@utk.edu).

${ }^{2}$ University of Tennessee, Department of Plant Sciences, Knoxville, 252 Ellington Plant Sciences, 2431 Joe Johnson Drive, Knoxville, TN 37996-4561, USA.

Received: 14 November 2011.

Accepted: 25 May 2012.

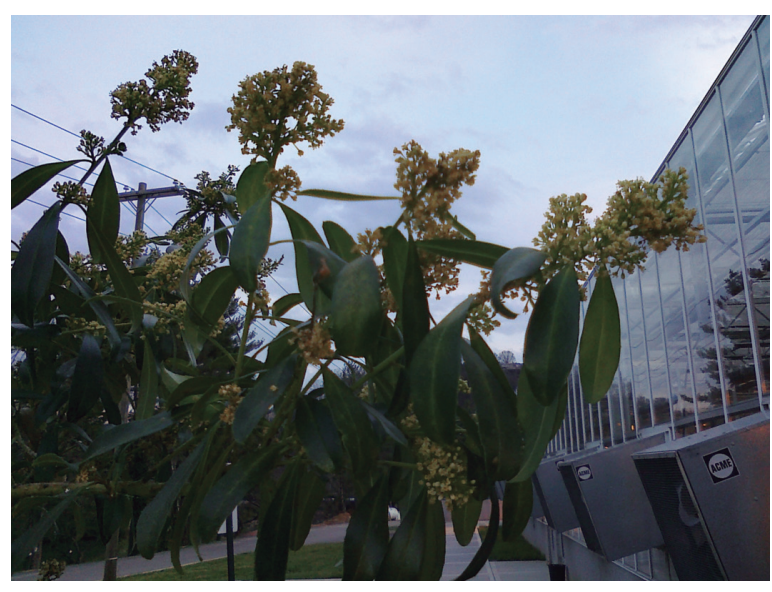

Figure 1. Yerba mate (Ilex paraguariensis) plant grown in the greenhouse in Knoxville, Tennessee. Approximately 24-mo old and $1.2 \mathrm{~m}$ tall.

Argentina was the first significant exporter of yerba mate and is second behind Uruguay for highest per capita consumption (Heck and de Mejia, 2007). In 2004, the total value of mate production in the world was estimated at US\$1 billion (Heck and de Mejia, 2007). Yerba mate is commercially produced from plants grown and harvested from plantations and natural forests (Heck et al., 2008). Once harvested, commercial yerba mate undergoes a series of processing steps before the final product is packaged: harvesting, roasting, drying, milling, and aging. 
Specific steps vary depending on the geographic region where the tea will be consumed (Heck and de Mejia, 2007; Heck et al., 2008). Several recent studies have examined the phytochemical content of yerba mate under different growth and processing conditions (Schmalko and Alzamora, 2001; Esmelindro et al., 2002; Giulian et al., 2009; Isolabella et al., 2010). Growing and processing conditions both have been shown to have an effect on the chemical composition of the I. paraguariensis (Heck et al., 2008), thus influencing the pharmacological properties.

The composition of yerba mate has been partially characterized and it includes a variety of polyphenols, xanthines, caffeoyl derivatives, saponins, and minerals that may be responsible for pharmacological activity (Alikaridis, 1987; Gosmann and Schenkel, 1989; Carini et al., 1998; Clifford and Ramírez-Martínez, 1990; Filip et al., 2001; Bastos et al., 2006; 2007; Bravo et al., 2007; Cardozo et al., 2007; Heck and de Mejia, 2007; Marques and Farah, 2009) (Table 1). Studies have suggested that yerba mate leaves may have antioxidant (Gugliucci and Stahl, 1995; Carini et al., 1998; Filip et al., 2000; Bastos et al., 2006; Anesini et al., 2006; Bastos et al., 2007; Pagliosa et al., 2010), antiobesity (Andersen and Fogh, 2001), antidiabetic (Lunceford and Gugliucci, 2005), diuretic (Gorgen et al., 2005), chemopreventative, antifungal (Filip et al., 2010), and stimulant (Filip et al., 1998; Athayde et al., 2000) properties. It may also aid in digestion (Gorzalczany et al., 2001). Yerba mate has been recognized for a variety of pharmacological activities, but limited research has been conducted on its antimicrobial properties (Kubo et al., 1993; Hongpattarakere, 2000; Sari et al., 2007; Tsai et al., 2008; Burris et al., 2011).

The use of yerba mate as an antimicrobial in foods and for crop protection is a relatively new concept (Racanicci et al., 2009; Burris et al., 2011) and has not been fully studied and reviewed. Crude extracts, i.e. tea, and a variety of isolated compounds derived from yerba mate have been shown to be active against a broad spectrum of Gram-positive and Gram-negative bacteria (Kubo et al., 1993; Hongpattarakere, 2000; Sari et al., 2007; Tsai et al., 2008; Burris et al., 2011). This points to possible use of crude extracts and isolated compounds as novel antimicrobials in foods.

The objective of this paper was to review the composition of yerba mate, the effect of cultivation, production, and processing has on its composition, and focus on those compounds that have bioactive properties.

\section{CULTIVATION AND PROCESSING}

Yerba mate can be cultivated and processed in a variety of ways. Typically, yerba mate is grown in two different environments-plantations or natural forests. Plantations are the more popular growth environment because of ease of harvest and a more consistent production quality and quantity (Heck et al., 2008). Yerba mate processing occurs in six steps: harvesting, roasting, drying, milling aging, and blending/packing (Isolabella et al., 2010). The leaves and small stems are harvested mechanically, divided into $100 \mathrm{~kg}$ sacks, and transported to a processing facility. Roasting, which inactivates enzymes and preserves sensory qualities, occurs by direct contact with fire at temperatures between 250 and $550^{\circ} \mathrm{C}$ for 2 to $4 \mathrm{~min}$ (Isolabella et al., 2010). Drying takes place by exposure to hot air until moisture content of $3 \%$ is attained. The drying process typically takes 12 to $14 \mathrm{~h}$ (Isolabella et al., 2010). There is little information on the effect of culture and processing conditions on bioactive properties of yerba mate. Heck et al. (2008) examined the effects of growing and drying conditions on the phenolic composition of yerba mate, and found plantation grown yerba mate had higher levels of phenolic acids compared to forest grownmate (Heck et al., 2008), demonstrating cultivation and processing can have a significant effect on the production and concentration of phytochemicals.

\section{Primary chemical composition of yerba mate}

Phenolic compounds. Structurally, polyphenols are comprised of a benzene ring that is bound with one or more hydroxyl groups. Polyphenols are derived from

Table 1. Main bioactive compounds found in Yerba Mate and their health benefits.

\begin{tabular}{|c|c|c|c|}
\hline $\begin{array}{l}\text { Chemical } \\
\text { compound }\end{array}$ & $\begin{array}{c}\text { Dry weight } \\
\text { composition ca. } \%\end{array}$ & Known health benefits & References \\
\hline Caffeoyl derivatives & 10.000 & & (Filip et al., 2001) \\
\hline Chlorogenic acid & 2.800 & Antioxidant, antimicrobial, antidiabetic, analgesic & (Filip et al., 2001) \\
\hline Caffeic acid & 0.023 & Antioxidant & (Filip et al., 2000; 2001; Heck and de Mejia, 2007) \\
\hline 3,4-DCQ & 0.855 & Anticancer, antioxidant & (Filip et al. 2001; Arbiser et al., 2005) \\
\hline 3,5-DCQ & 3.040 & Anticancer, antioxidant & (Filip et al., 2001; Arbiser et al., 2005) \\
\hline 4,5-DCQ & 2.890 & & (Filip et al., 2001) \\
\hline Saponins & 5 to 10 & Anticancer, Anti-inflammation, antiparasitic & (Taketa et al., 2004b; Puangpraphant et al., 2011) \\
\hline \multicolumn{4}{|l|}{ Xanthines } \\
\hline Caffeine & 1 to $2 \%$ & Anticarcinogenic, antiobesity, antioxidant, diuretic, stimulant, vasodilator & (Ito et al. 1997; Heck and de Mejia, 2007) \\
\hline Theobromine & 0.3 to $0.9 \%$ & Stimulant, diuretic & (Ito et al., 1997; Heck and de Mejia, 2007) \\
\hline Theophylline & 0 to trace & Stimulant, vasodilator & (Ito et al., 1997; Heck and de Mejia, 2007) \\
\hline Rutin & 0.060 & Antioxidant, lipoxygenase-inhibitor, anticancer, anti-tumor, anti-ulcer & (Arbiser et al., 2005; Heck and de Mejia, 2007) \\
\hline Quercetin & 0.0031 & Anticancer, anti-inflammation, antimicrobial & $\begin{array}{l}\text { (Rauha et al., 2000; Arbiser et al., 2005; Puang } \\
\text { praphant and de Mejia, 2009) }\end{array}$ \\
\hline Kaempferol & 0.0012 & Anti-inflammation, antimicrobial & $\begin{array}{l}\text { (Rauha et al., 2000; Puangpraphant and de Mejia, } \\
\text { 2009) }\end{array}$ \\
\hline
\end{tabular}


mate plants and are considered its major bioactive compounds. The level of polyphenolics in yerba mate extracts are greater than those of green tea and similar to levels found in red wine (Gugliucci et al., 2009; Gugliucci and Bastos, 2009). The polyphenols in yerba mate include caffeic acid, caffeine, caffeoyl derivatives, caffeoylshikimic acid, chlorogenic acid, feruloylquinic acid, kaempferol, quercetin, quinic acid, rutin, and theobromine (Carini et al., 1998; Chandra and De Mejia Gonzalez, 2004; Atoui et al., 2005; Bastos et al., 2007; Bravo et al., 2007) with caffeoyl derivatives accounting for approximately $10 \%$ of the dry weight (Filip et al., 2001) (Table 1). A number of growing and processing factors can affect the amount of polyphenols extracted from yerba mate (Heck et al., 2008; Isolabella et al., 2010). Additionally, the method of consumption can have an influence on extracted polyphenolics (Meinhart et al., 2010). A total infusion preparation with cold water, termed 'terere', demonstrated the extraction of almost all phenolics (Meinhart et al., 2010). It was found that green leaves contained significantly lower concentrations of active compounds, caffeoyl derivative, methylxanthines and flavonoids, as compared to those leaves that had undergone processing, drying and aging (Isolabella et al., 2010). Yerba mate extracts are highly rich in chlorogenic acids, and unlike green tea, contain no catechins (Chandra and De Mejia Gonzalez, 2004). According to (Dall'Orto et al., 2005), on average, approximately $92 \mathrm{mg}$ equivalent chlorogenic acid was extracted from each gram of yerba mate leaves. Jaiswal et al. (2010) detected and characterized 42 chlorogenic acids isomers based from yerba mate using LC-MS-eight caffeoylquinic acids, five dicaffeoylquinic acids, six feruloylquinic acids, two diferuloyl quinic acids, five p-coumaroylquinic acids, four caffeoyl-p-coumaroylquinic acids, seven caffeoylferuloylquinic acids, three caffeoyl-sinapoylquinic acids, one tricaffeoylquinic acid, and one dicaffeoylferuloylquinic acid.

The polyphenolic content of yerba mate has been shown to be strongly related to its overall antioxidant capacity (Chandra and De Mejia Gonzalez, 2004) similar to green tea. Polyphenols are reducing agents and have been reported to provide body tissues protection from oxidative stress that causes aging, cancer, cardiovascular disease and inflammation (Ames et al., 1993; Scalbert et al., 2005).

Saponins. Saponins are glycosidic compounds that are generally water-soluble and foam upon shaking (Bastos et al., 2007). The primary saponins identified from yerba mate are matesaponin 1 through 5 (Gosmann and Schenkel, 1989; Gosmann et al., 1995; Kraemer et al., 1996). Matesaponin 1 was first discovered by Gosmann and Schenkel (1989) with a chemical structure of ursolic acid-3-0-[ $\beta$-D-glucopyranosyl- $(1 \rightarrow 3)$ - $\alpha$-L-arabinopyranosyl]-(28 $\rightarrow 1)-\beta$-D-glucopyranosyl ester. Gosmann et al. (1995) then discovered and structurally determined three more saponins, matesaponin 2 through 4. Yerba mate leaves have a relatively high saponin content, 5 to $10 \%$ of the total dry weight. Puangpraphant et al. (2011) quantified and purified saponins from dried mate leaves and obtained 10 to $15 \mathrm{mg} \mathrm{g}^{-1}$ dry weight total saponins, mainly matesaponins 1 and 2 (Puangpraphant et al., 2011). The method of consumption of yerba mate influences the amount of xanthines extraction. Meinhart et al. (2010) determined that the highest quantities of xanthines were extracted from partial infusions with hot water.

Saponins have been reported to provide a hypocholesteremic effect by inhibiting the passive diffusion of colic acid through the formation of micelles preventing absorption, anticancer, antiparasitic (Taketa et al., 2004a; 2004b), and anti-inflammatory properties.

Xanthines. Xanthines are a class of purine alkaloids found in many different plants. There are three xanthines found in yerba mate, caffeine, theobromine, and theophyline, and give yerba mate its characteristic bitter flavor and stimulant effects (Filip et al., 1998; Athayde et al., 2000; Gorgen et al., 2005). Of these, caffeine is present in the highest concentrations at 1 to $2 \%$ of total dry weight, followed by theobromine at 0.3 to $0.9 \%$ of total dry weight (Ito et al., 1997) (Table 1). The consumption of caffeine found in a cup of yerba mate (78 $\mathrm{mg}$ ) is similar to that of a cup of coffee ( $85 \mathrm{mg})$; however, the typical method of yerba mate consumption involving repeatedly pouring additional hot water over in the 'mate' can yield intakes greater than $260 \mathrm{mg}$ of caffeine per serving, attributed to percent stem or woody content and extraction rate. Processing by three-stage drying was shown to significantly decrease caffeine content by $30 \%$ (Schmalko and Alzamora, 2001). However, Bastos et al. (2006) found that dried leaves had significantly higher amounts of caffeine than fresh leaves.

\section{BIOACTIVE PROPERTIES AND HEALTH IMPLICATIONS}

\section{Antimicrobial and oral health}

Relatively limited research has been conducted on isolation and identification of compounds possessing antimicrobial activity derived from yerba mate (Kubo et al., 1993; Hongpattarakere, 2000; Sari et al., 2007; Tsai et al., 2008; Filip et al., 2010). Filip et al. (2010) identified caffeoyl derivatives, methylxanthines, and rutin from yerba mate aqueous extracts with antifungal activity. N-hexane extracts of yerba mate have been shown to be effective antimicrobial agents against the oral bacterium, Streptococcus mutans (Kubo et al., 1993). The 10 main compounds identified as potential antimicrobial components were linalool, $\alpha$-ionone, $\beta$-ionone, $\alpha$-terpineol, octanoic acid, geraniol, 1-octanol, nerolidol, geranylactetone, and eugenol (Kubo et al., 1993). These 
compounds have been shown to be active against a broad spectrum of Gram-positive and Gram-negative bacteria, with effective levels between 12.5 and $1600 \mu \mathrm{g} \mathrm{mL}^{-1}$ (Taniguchi et al., 1978; Kubo et al., 1991; 1993; Sari et al., 2007). The Gram-positive bacteria, Bacillus subtilis, Brevibacterium ammoniagenes, Propionibacterium acnes, Staphylococcus aureus, and Streptococcus mutans, and five fungi, Saccharomyces cerevisiae, Candida utilis, Pityrosporum ovale, Penicillium chrysogenum, and Trichophyton mentagrophytes, were inhibited by at least one of the ten identified compounds tested (Kubo et al., 1993). None of the extracts tested were effective against the Gram-negative bacteria, Pseudomonas aeruginosa or Enterobacter aerogenes and were found to be only weakly active against Escherichia coli (Kubo et al., 1993). Burris et al. (2011) determined that aqueous extracts from yerba mate demonstrated antimicrobial activity against $S$. aureus and $E$. coli $\mathrm{O} 157: \mathrm{H} 7$, indicating inhibition and inactivation of both Gram-positive and Gram-negative bacteria. This finding suggests that an additional compound is present in the aqueous extract that provides activity in addition to the 10 identified by Kubo et al. (1993).

While many of the major compounds found in yerba mate extracts are known (Kubo et al., 1993; Hongpattarakere, 2000; Heck and de Mejia, 2007), contradictory information is available on which compounds might contribute to antimicrobial activity and whether they may have additive or synergistic effects in combination. Polyphenols identified in yerba mate include caffeic acid, caffeine, caffeoyl derivatives, caffeoylshikimic acid, chlorogenic acid, feruloylquinic acid, kaempferol, quercetin, quinic acid, rutin, and theobromine (Heck and de Mejia, 2007; Marques and Farah, 2009) all of which contribute to the antimicrobial activity against foodborne pathogens. Caffeic and chlorogenic acids in their pure form have demonstrated activity against Gram-negative bacteria (Herald and Davidson, 1983; Puupponen-Pimia et al., 2001). However, Kubo et al. (1993) found that the three main compounds found in yerba mate, caffeine, ursolic acid and chlorogenic acid, did not demonstrate antimicrobial activity against Gram-negative or Grampositive bacteria, including E. coli and S. aureus. Further, Rauha et al. (2000) found caffeic acid did not demonstrate inhibitory activity against the Gram-positive bacteria, S. aureus, S. epidermidis, or Bacillus subtilis. However, Herald and Davidson (1983) demonstrated a reduction in viable $S$. aureus at $\mathrm{pH} 5.0$ by p-coumeric acid. No inhibition against Streptococcus mutans has been observed with caffeine (Daglia et al., 2002), indicating caffeine was not contributing to activity observed by Kubo et al. (1993). Several of the flavonols found in yerba mate have also been examined for their antimicrobial activity-kaempferol, quercetin, and rutin (Panizzi et al., 2002; Rauha et al., 2000). Kaempferol did not to inhibit S.epidermidis (Rauha et al., 2000) or E. coli (Puupponen-Pimia et al., 2001); however, it demonstrated antimicrobial activity against $S$. aureus (Rauha et al., 2000). Similarly, quercetin exhibited strong inhibition against $S$. aureus, but unlike kaempferol, provided strong to moderate activity against $S$. epidermidis and B. subtilis respectively (Rauha et al., 2000). Results from Panizzi et al. (2002) were contradictory to these, where neither kaempferol nor quercetin demonstrated antimicrobial activity against $S$. aureus or E. coli. Rutin did not demonstrate any activity against $S$. aureus, $S$. epidermidis or B. subtilis (Rauha et al., 2000).

Caffeoylquinic acid derivatives have been shown to contribute to antimicrobial activity in other crude plant extracts (Chakraborty and Mitra, 2008) and have been found in yerba mate extract (Filip et al., 2000; 2010). It is likely a combination of compounds found in yerba mate extracts is contributing to the antimicrobial activity against Gram-negative and Gram-positive bacteria as evidenced by the ineffectiveness of activity of some individual compounds.

\section{Antioxidant, anti-obesity, anti-inflammation}

The pharmacological properties-antioxidant, antiobesity and anti-inflammation - of yerba mate extracts and compounds have been previously reviewed (Bastos et al., 2007; Heck and de Mejia, 2007; Bracesco et al., 2010). Oxygen radicals are involved in many human diseases including cancer, inflammation, liver and cardiovascular disease (Ames et al., 1993; Halliwell, 1994). Yerba mate extracts have been previously shown to provide antioxidant activity and inhibition of low-densitylipoproteins oxidation (Gugliucci and Stahl, 1995; Filip et al., 2000; Chandra and De Mejia Gonzalez, 2004) in vitro (Gugliucci and Stahl, 1995; Filip et al., 2000) and in vivo (Gugliucci, 1996; Schinella et al., 2000; Lanzetti et al., 2008). Similarly, Martins et al. (2009) determined that mice fed yerba mate had lower thiobarbituric acid reactive substances in the liver, suggesting that treatment with yerba mate extract protected unsaturated fatty acids from oxidation and may especially protect the liver (Martins et al., 2009).

According to Andersen and Fogh (2001), in overweight patients, yerba mate extract significantly delayed gastric emptying, decreased the perceived time to fullness and ultimately induced a significant weight loss after $45 \mathrm{~d}$. Arcari et al. (2009) demonstrated that treatment with yerba mate extract has potent anti-obesity effects in adipose tissue in vivo by controlling the expression of several genes related to obesity processes, such as inflammatory markers.

Inflammation is a factor in many human diseases: cancer, cardiovascular disease, obesity, and diabetes.

Lanzetti et al. (2008) determined that yerba mate reduced acute lung inflammation in mice exposed to cigarette smoke. Recently, Puangpraphant and de Mejia (2009) investigated the potential anti-inflammatory effect of yerba mate extracts as well as some of its compound 
and their interactions. Quercetin was determined the most potent inhibitor of pro-inflammatory responses at a concentration 10 times lower than that of other tested compounds (Puangpraphant and de Mejia, 2009).

\section{CONCLUSIONS}

Plants have been used as a source of bioactive compounds for thousands years. However, within the last decade, the want and need for more natural, bioactive compounds has grown. Research on extracts and isolated compounds from yerba mate to benefit human health has provided a number of pharmacological applications: antioxidant, antimicrobial, anti-inflammatory, antiobesity, and anticancer. With the potential use of yerba mate extracts as antimicrobials in foods, sensory qualities must be addressed. One common negative factor associated with the use of plant extracts as antimicrobial food preservatives is their effect on food sensory (flavor, odor) properties. The flavor of yerba mate infusions has been described in various terms, such as bitter, acid, astringent, hay, green, humid, toasted, and paper. However, use of yerba mate (dried and aqueous extracts) had no effect on the taste or smell of precooked chicken meat balls.

While the need for more research on the isolation and identification of bioactive compounds exists, evidence seems to demonstrate that yerba mate is a botanical with a variety of compounds that can be applied for use in human health. Research confirms the influence cultivation and processing have on the chemical composition of yerba mate and demonstrates their importance in the production of bioactive compounds. Further research can be explored to optimize growth and processing technologies to enhance bioactive compounds for use in foods, crops, cosmetics, nutraceuticals, and supplements to support human health.

\section{Composición y propiedades bioactivas de la yerba mate} (Ilex paraguariensis A. St.-Hil.): una revisión. Yerba mate es una infusión popular producida y consumida en Argentina, Brasil, Chile, Paraguay y Uruguay. Se procesa a partir de hojas y tallos de Ilex paraguariensis A. St.Hil., un arbusto perenne de la familia Aquifoliaceae. El procesamiento ocurre en seis etapas: recolección de hojas maduras y tallos pequeños, tostado por fuego directo, secado por aire caliente, molienda, envejecimiento (dependiendo de los atributos sensoriales requeridos), y embalaje final. Si bien la yerba mate se ha cultivado y consumido por siglos en América del Sur, su popularidad en los Estados Unidos ha aumentando debido a la demanda por bebidas saludables y alimentos más naturales y por los potenciales beneficios para la salud de la yerba mate (antioxidante, antimicrobiano, acción contra la obesidad y diabetes, digestivo, estimulante). La yerba mate también se ha investigado como agente de prevención y causa de algunos tipos de cáncer, causando controversia entre investigadores. Investigaciones recientes han ampliado el espectro de uso de la yerba mate como agente antimicrobiano, protección de cultivos y acción contra patógenos transmitidos por alimentos. Resultados prometedores para el uso de esta planta en la salud humana y animal han llevado a esta revisión. Esta revisión se centró en la composición de la yerba mate, y el efecto que el cultivo y el procesamiento puede tener sobre sus propiedades.

Palabras clave: antioxidantes, antimicrobianos, natural productos, yerba mate, té.

\section{LITERATURE CITED}

Alikaridis, F. 1987. Natural constituents of Ilex species. Journal of Ethnopharmacology 20:121-144.

Ames, B.N., M.K. Shigenaga, and T.M. Hagen. 1993. Oxidants, antioxidants, and the degenerative diseases of aging. Proceedings of the National Academy of Sciences USA 90:7915-7922.

Andersen, T., and J. Fogh. 2001. Weight loss and delayed gastric emptying following a South American herbal preparation in overweight patients. Journal of Human Nutrition and Dietetics 14:243-250.

Anesini, C., G. Ferraro, and R. Filip. 2006. Peroxidase-like activity of Ilex paraguariensis. Food Chemistry 97:459-464.

Arbiser, J.L., X.C. Li, C.F. Hossain, D.G. Nagle, D.M. Smith, P. Miller, et al. 2005. Naturally occurring proteasome inhibitors from mate tea (Ilex paraguayensis) serve as models for topical proteasome inhibitors. Journal of Investigative Dermatology 125:207-212.

Arcari, D.P., W. Bartchewsky, T.W. dos Santos, K.A. Oliveira, A. Funck, J. Pedrazzoli, et al. 2009. Antiobesity effects of yerba mate extract (Ilex paraguariensis) in high-fat diet-induced obese mice. Obesity 17:2127-33.

Athayde, M.L., G.C. Coelho, and E.P. Schenkel. 2000. Caffeine and theobromine in epicuticular wax of Ilex paraguariensis A. St.-Hil Phytochemistry 55:853-857.

Atoui, A.K., M. Abdelhak, G. Boskou, and P. Kefalas. 2005. Tea and herbal infusions: their antioxidant activity and phenolic profile. Food Chemistry 89:27-36.

Bastos, D.H.M., E.Y. Ishimoto, M.O.M. Marques, A.F. Ferri, and E.A.F.S. Torres. 2006. Essential oil and antioxidant activity of green mate and mate tea (Ilex paraguariensis) infusions. Journal of Food Composition and Analysis 19:538-543.

Bastos, D.H.M., L.A. Saldanha, R.R. Catharino, A.C.H.F. Sawaya, I.B.S. Cunha, P.O. Carvalho, and M.N. Eberlin. 2007. Phenolic antioxidants identified by ESI-MS from yerba mate (Ilex paraguariensis) and green tea (Camelia sinensis) extracts. Molecules 12:423-432.

Bracesco, N., A.G. Sanchez, V. Contreras, T. Menini, and A. Gugliucci. 2010. Recent advances on Ilex paraguariensis research: Minireview. Journal of Ethnopharmacology 136:378384. doi:10.1016/j.jep.2010.06.032.

Bravo,L., L. Goya, and E. Lecumberri. 2007. LC/MS characterization of phenolic constituents of mate (Ilex paraguariensis, St. Hil.) and its antioxidant activity compared to commonly consumed beverages. Food Research International 40:393-405.

Burris, K.P., P.M. Davidson, C.N. Stewart Jr., and F. Harte. 2011. Antimicrobial activity of yerba mate (Ilex paraguariensis) aqueous extracts against Escherichia coli O157:H7 and Staphylococcus aureus. Journal of Food Science 76(6):M456-M462.

Cardozo, Jr. E.L., O. Ferrarese-Filho, L.C. Filho, M.D.L.L. Ferrarese, C.M. Donaduzzi, and J.A. Sturion. 2007. Methylxanthines and phenolic compounds in mate (Ilex paraguariensis St. Hil.) progenies grown in Brazil. Journal of Food Composition and Analysis 20:553-558. 
Carini, M., R.M. Facino, G. Aldini, M. Calloni, and L. Colombo. 1998. Characterization of phenolic antioxidants from mate (Ilex paraguayensis) by liquid chromatography mass spectrometry and liquid chromatography tandem mass spectrometry. Rapid Communications in Mass Spectrometry 12:1813-1819.

Chakraborty, M., and A. Mitra. 2008. The antioxidant and antimicrobial properties of the methanolic extract from Cocos nucifera mesocarp. Food Chemistry 107:994-999.

Chandra, S., and E. De Mejia Gonzalez. 2004. Polyphenolic compounds, antioxidant capacity, and quinone reductase activity of an aqueous extract of Ardisia compressa in comparison to mate (Ilex paraguariensis) and green (Camellia sinensis) teas. Journal of Agricultural and Food Chemistry 52:3583-3589.

Clifford, M.N., and J.R. Ramirez-Martinez. 1990. Chlorogenic acids and purine alkaloids contents of mate (Ilex paraguariensis) leaf and beverage. Food Chemistry 35:13-21.

Daglia, M., R. Tarsi, A. Papetti, P. Grisoli, C. Dacarro, C. Pruzzo, and G. Gazzani. 2002. Antiadhesive effect of green and roasted coffee on Streptococcus mutans' adhesive properties on salivacoated hydroxyapatite beads. Journal of Agricultural and Food Chemistry 50:1225-1229.

Dall'Orto, V.C., J.M. Vago, R.R. Carballo, and I.N. Rezzano. 2005. Comparison of tyrosinase biosensor and colorimetric method for polyphenol analysis in different kinds of teas. Analytical Letters 38:19-33.

Esmelindro, M.C., G. Toniazzo, A. Waczuk, C. Dariva, and D.d. Oliveira. 2002. Effects of industrial processing steps on the physico-chemical characteristics of mate tea leaves. Ciencia e Tecnologia de Alimentos 22:199-204.

Filip, R., R. Davicino, and C. Anesini. 2010. Antifungal activity of the aqueous extract of Ilex paraguariensis against Malassezia furfur. Phytotherapy Research 24:715-719.

Filip, R., P. Lopez, J. Coussio, and G. Ferraro. 1998. Mate substitutes or adulterants: study of xanthine content. Phytotherapy Research 12:129-131

Filip, R., P. Lopez, G. Giberti, J. Coussio, and G. Ferraro. 2001. Phenolic compounds in seven South American Ilex species. Fitoterapia 72:774-778.

Filip, R., S.B. Lotito, G. Ferraro, and C.G. Fraga. 2000. Antioxidant activity of Ilex paraguariensis and related species. Nutrition Research 20:1437-1446.

Giulian, R., C.E.I.D. Santos, S.D.M. Shubeita, L.M.D. Silva, M.L. Yoneama, and J.F. Dias. 2009. The study of the influence of industrial processing on the elemental composition of mate tea leaves (Ilex paraguariensis) using the PIXE technique. Lebenson Wiss Technology-Food Science and Technology 42:74-80.

Gorgen, M., K. Turatti, A.R. Medeiros, A. Buffon, C.D. Bonan, J.J.F. Sarkis, and G.S. Pereira. 2005. Aqueous extract of Ilex paraguariensis decreases nucleotide hydrolysis in rat blood serum. Journal of Ethnopharmacology 97:73-77.

Gorzalczany, S., R. Filip, M.D. Alonso, J. Mino, G.E. Ferraro, and C. Acevedo. 2001. Choleretic effect and intestinal propulsion of 'mate' (Ilex paraguariensis) and its substitutes or adulterants. Journal of Ethnopharmacology 75:291-294.

Gosmann, G., D. Guillaume, A.T. Taketa, and E.P. Schenkel. 1995. Triterpenoid saponins from Ilex paraguariensis. Journal of Natural Products 58:438-441.

Gosmann, G., and E.P. Schenkel. 1989. A new saponin from Mate, Ilex paraguariensis. Journal of Natural Products 52:1367-1370.

Grigioni, G., F. Carduza, M. Irurueta, and N. Pensel. 2004. Flavour characteristics of Ilex paraguariensis infusion, a typical Argentine product, assessed by sensory evaluation and electronic nose. Journal of the Science of Food and Agriculture 84:427-432.

Gugliucci, A. 1996. Antioxidant effects of Ilex paraguariensis: induction of decreased oxidability of human LDL in vivo. Biochemical and Biophysical Research Communications 224:338-344.

Gugliucci, A., and D.H. Bastos. 2009. Chlorogenic acid protects paraoxonase 1 activity in high density lipoprotein from inactivation caused by physiological concentrations of hypochlorite. Fitoterapia 80:138-142.
Gugliucci, A., D.H. Bastos, J. Schulze, and M.F. Souza. 2009. Caffeic and chlorogenic acids in Ilex paraguariensis extracts are the main inhibitors of AGE generation by methylglyoxal in model proteins. Fitoterapia 80:339-344.

Gugliucci, A., and A.J.C. Stahl. 1995. Low-density-lipoprotein oxidation is inhibited by extracts of Ilex paraguariensis. Biochemistry and Molecular Biology International 35:47-56.

Halliwell, B. 1994. Free radicals and antioxidants: a personal view. Nutrition Reviews 52:253-65.

Heck, C.I., and E.G. de Mejia. 2007. Yerba Mate Tea (Ilex paraguariensis): a comprehensive review on chemistry, health implications, and technological considerations. Journal of Food Science 72:R138-151.

Heck, C.I., M. Schmalko, and E. Gonzalez de Mejia. 2008. Effect of growing and drying conditions on the phenolic composition of mate teas (Ilex paraguariensis). Journal of Agricultural and Food Chemistry 56:8394-8403.

Herald, P.J., and P.M. Davidson. 1983. Antibacterial activity of selected hydroxycinnamic acids. Journal of Food Science 48:1378-1379.

Hongpattarakere, T. 2000. Natural antimicrobial components isolated from Yerba Mate (Ilex paraguariensis) leaves. 189 p. $\mathrm{Ph} . \mathrm{D}$. dissertation. University of Wisconsin, Madison, Wisconsin, USA.

Isolabella, S., L. Cogoi, P. Lopez, C. Anesini, G. Ferraro, and R. Filip. 2010. Study of the bioactive compounds variation during yerba mate (Ilex paraguariensis) processing. Food Chemistry 122:695-699.

Ito, E., A. Crozier, and H. Ashihara. 1997. Theophylline metabolism in higher plants. Biochimica et Biophysica Acta 1336:323-330.

Jaiswal, R., T. Sovdat, F. Vivan, and N. Kuhnert. 2010. Profiling and characterization by LC-MSn of the chlorogenic acids and hydroxycinnamoylshikimate esters in mate (Ilex paraguariensis). Journal of Agricultural and Food Chemistry 58:5471-5484.

Kraemer, K.H., A.T.C. Taketa, E.P. Schenkel, G. Gosmann, and D. Guillaume. 1996. Matesaponin 5, a highly polar saponin from Ilex paraguariensis. Phytochemistry 42:1119-1122.

Kubo, I., M. Himejima, and H. Muroi. 1991. Antimicrobial activity of flavor components of cardamom Elattaria cardamomum (Zingiberaceae) seed. Journal of Agricultural and Food Chemistry 39:1984-1986.

Kubo, I., H. Muroi, and M. Himejima. 1993. Antibacterial activity against Streptococcus mutans of mate tea flavor components. Journal of Agricultural and Food Chemistry 41:107-111.

Lanzetti, M., F.S. Bezerra, B. Romana-Souza, A.C. Brando-Lima, V.L.G. Koatz, L.C. Porto, and S.S. Valenca. 2008. Mate tea reduced acute lung inflammation in mice exposed to cigarette smoke. Nutrition 24:375-381.

Lunceford, N., and A. Gugliucci. 2005. Ilex paraguariensis extracts inhibit AGE formation more efficiently than green tea. Fitoterapia 76:419-427

Marques, V., and A. Farah. 2009. Chlorogenic acids and related compounds in medicinal plants and infusions. Food Chemistry 113:1370-1376

Martins, F., A.J. Suzan, S.M. Cerutti, D.P. Arcari, M.L. Ribeiro, D.H. Bastos, and O. Carvalho Pde. 2009. Consumption of mate tea (Ilex paraguariensis) decreases the oxidation of unsaturated fatty acids in mouse liver. British Journal of Nutrition 101:527-532.

Meinhart, A.D., C.S. Bizzotto, C.A. Ballus, A.C. Poloni Rybka, M.R. Sobrinho, R.S. Cerro-Quintana, et al. 2010. Methylxanthines and phenolics content extracted during the consumption of mate (Ilex paraguariensis St. Hil) beverages. Journal of Agricultural and Food Chemistry 58:2188-2193.

Pagliosa, C.M., M.A. Vieira, R. Podestá, M. Maraschin, A.L.B. Zeni, E.R. Amante, and R.D.D.M.C. Amboni. 2010. Methylxanthines, phenolic composition, and antioxidant activity of bark from residues from mate tree harvesting (Ilex paraguariensis A. St. Hil.). Food Chemistry 122:173-178.

Panizzi, L., C. Caponi, S. Catalano, P.L. Cioni, and I. Morelli. 2002. In vitro antimicrobial activity of extracts and isolated constituents of Rubus ulmifolius. Journal of Ethnopharmacology 79:165-168. 
Puangpraphant, S., M.A. Berhow, and E.G. de Mejia. 2011. Mate (Ilex paraguariensis St Hilaire) saponins induce caspase-3dependent apoptosis in human colon cancer cells in vitro. Food Chemistry 125:1171-1178.

Puangpraphant, S., and E.G. de Mejia. 2009. Saponins in yerba mate tea (Ilex paraguariensis A. St.-Hil) and quercetin synergistically inhibit iNOS and COX-2 in lipopolysaccharide-induced macrophages through NFxB pathways. Journal of Agricultural and Food Chemistry 57:8873-8883.

Puupponen-Pimia, R., L. Nohynek, C. Meier, M. Kahkonen, M. Heinonen, A. Hopia, and K. M. Oksman-Caldentey. 2001 Antimicrobial properties of phenolic compounds from berries. Journal of Applied Microbiology 90:494-507.

Racanicci, A.M.C., B.H. Allesen-Holm, and L.H. Skibsted. 2009. Sensory evaluation of precooked chicken meat with mate (Ilex paraguariensis) added as antioxidant. European Food Research and Technology 229:277-280.

Rauha, J.P., S. Remes, M. Heinonen, A. Hopia, M. Kahkonen, T. Kujala, et al. 2000. Antimicrobial effects of Finnish plant extracts containing flavonoids and other phenolic compounds. International Journal of Food Microbiology 56:3-12.

Sari, F., N. Turkmen, G. Polat, and Y.S. Velioglu. 2007. Total polyphenol, antioxidant and antibacterial activities of black mate tea. Food Science and Technology Research 13:265-269.
Scalbert, A., C. Manach, C. Morand, C. Remesy, and L. Jimenez. 2005. Dietary polyphenols and the prevention of diseases. Critical Reviews in Food Science and Nutrition 45:287-306.

Schinella, G.R., G. Troiani, V. Davila, P.M. de Buschiazzo, and H.A. Tournier. 2000. Antioxidant effects of an aqueous extract of Ilex paraguariensis. Biochemical and Biophysical Research Communications 269:357-360.

Schmalko, M.E., and S.M. Alzamora. 2001. Color, chlorophyll, caffeine, and water content variation during yerba mate processing. Drying Technology 19:599-610.

Taketa, A.T.C., E. Breitmaier, and E.P. Schenkel. 2004a. Triterpenes and triterpenoidal glycosides from the fruits of Ilex paraguariensis (Mate). Journal of the Brazilian Chemical Society 15:205-211.

Taketa, A.T.C., S.C.B. Gnoatto, G. Gosmann, V.S. Pires, E.P. Schenkel, and D. Guillaume. 2004b. Triterpenoids from Brazilian Ilex species and their in vitro antitrypanosomal activity. Journal of Natural Products 67:1697-1700.

Taniguchi, M., A. Chapya, I. Kubo, and K. Nakanishi. 1978. Screening of East-African plants for anti-microbial activity. Chemical and Pharmaceutical Bulletin 26:2910-2913.

Tsai, T.H., T.H. Tsai, Y.C. Chien, C.W. Lee, and P.J. Tsai. 2008. In vitro antimicrobial activities against cariogenic streptococci and their antioxidant capacities: A comparative study of green tea versus different herbs. Food Chemistry 110:859-864 